\title{
Correction to: Mesozoic Stratigraphy of India
}

\author{
Santanu Banerjee (D) and Subir Sarkar
}

\section{Correction to:}

S. Banerjee and S. Sarkar (eds.), Mesozoic Stratigraphy of India, Society of Earth Scientists Series, https://doi.org/10.1007/978-3-030-71370-6

In the original version of the book, belated corrections are updated for the following chapters:

Chapter "Nautiloid Biostratigraphy of the Jurassic of Kutch, India: An Exploration of Bio- and Chrono-stratigraphic Potential of Nautiloids"

The Table 1 has been formatted correctly

Chapter "Biostratigraphic Implications of the Calcareous Nannofossils from the Spiti Formation at Langza, Spiti Valley":

The affiliation "Department of Geology, School of Earth, Biological and Environmental Science, Central University of South Bihar, Gaya 824236, Bihar, India” of the author "Nazim Deori" has been changed to "Department of Earth and Environmental Sciences, K.S.K.V. Kachchh University, Bhuj, Gujarat, India”.

The correction chapters and book have been updated with the changes.

The updated version of these chapters can be found at https://doi.org/10.1007/978-3-030-71370-6_10 https://doi.org/10.1007/978-3-030-71370-6_15 